\title{
National Debt and Its Effects on Several Other Variables: An Econometric Study of the United States
}

\author{
Augustine C. Arize ${ }^{1}$, Ioannis N. Kallianotis ${ }^{2}$, Scott Liu ${ }^{3}$, John Malindretos ${ }^{4} \&$ Alex Panayides ${ }^{4}$ \\ ${ }^{1}$ Regents' Professor of Business Administration and MIS Department, College of Business and Technology, Texas \\ A\&M, USA \\ ${ }^{2}$ Department of Economics and Finance, The Arthur J. Kania School of Management, University of Scranton, USA \\ ${ }^{3}$ Executive Associate Dean for Global Programs, School of Management, New York Institute of Technology, USA \\ 4 Department of Economics, Finance and Global Business, Cotsakos College of Business, William Paterson \\ University, USA \\ Correspondence: John Malindretos, Department of Economics, Finance and Global Business, Cotsakos College of \\ Business, William Paterson University, USA. E-mail: jnmalindre@optonline.net
}

Received: June 4, 2014

doi:10.5430/ijfr.v5n4p98
Accepted: August 2, 2014

Online Published: September 5, 2014

URL: http://dx.doi.org/10.5430/ijfr.v5n4p98

\begin{abstract}
This paper uses a neoclassical open economy general equilibrium model to determine the effects of the budget deficit and national debt on some key domestic variables while examining the interdependence and repercussion effects between the U.S. economy and the rest of the world. The empirical results show that the budget deficit has a significant effect on both prices and the current account and that the international debt has a similar effect on consumption and saving. Foreign interest rate and foreign real income affect almost every variable in the United States. In the long run, the deficits might have negative effects on the U.S. economy and redistribution effects between generations.
\end{abstract}

Keywords: national debt, budget deficit, variable, effect

\section{Introduction}

A group of U.S. economists told a Joint Economic Committee hearing in 1989 that the budget deficit was causing a reduction in public investment in two areas critical to the nation's future. Those two areas are physical infrastructure (highways, bridges, mass transit, airports, water supply, and waste disposal) and children (investment in education for low- income children and youth). They named this failure to invest the "third deficit." (Note 1) Another disadvantage of the deficit that we experienced during the 1990 recession was the inability of the government to use fiscal policy to stimulate the economy.

There has been a great deal of public concern in the United States, especially during the 1992 presidential campaign, and in many other countries around the world about the rapid growth of national debts. Among economists, the grounds for concern most often stressed are that a higher public debt would reduce national savings (and, as a result, reduce capital accumulation), with negative consequences for future income and overall social welfare, at least in the long run. (Note 2) These consequences are predicted by what is often referred to by Bernheim (1989) as the "neoclassical" model, which is a general equilibrium version of the "life cycle" model of consumption and savings developed by Modigliani and associates.

According to an opposing view, the "Ricardian Equivalence Theorem," (Note 3) Barro (1989) asserts that changes in the level of public debt should have no effect at all (except insofar as the higher future taxes implied by a higher public debt distort incentives), so that this concern is largely misplaced. But many economists are skeptical about the practical relevance of the Ricardian view because of the apparent connection between government deficits and numerous aspects of economic activities and financial market conditions. (Note 4) For example, the high real interest rate of the 1980s is often attributed to the rapid growth of the U.S. public debt in this period. (Note 5) As a result, the other predictions of the neoclassical model are also widely accepted.

Some economists have proposed linkages among the U.S. deficit, dollar value, and unemployment. The assertion states that the large U.S. public deficit can place upward pressure on U.S. interest rates, which in turn would attract foreign 
demand for high-yield U.S. securities. This demand places upward pressure on the dollar's value, and this resulting capital inflow to the U.S. increases the capital account surplus (deteriorates the current account) and, due to a strengthening dollar, terms of trade deteriorate and exports fall. U.S. employment could then be indirectly (negatively) affected by the large U.S. budget deficit.

The above impact of the deficit on unemployment existed during the early 1980s. However, after 1985, the U.S. budget deficit was thought to reflect insufficient taxation, thereby stimulating consumer expenditures, some of which were on foreign goods. The insufficient taxation continued in the 2000s especially with the tax cut under the Bush administration.

\section{Review of the Literature}

The impact of government borrowing on economic activity has been a controversial issue in the literature since the days of Adam Smith and David Ricardo. Ricardo (1951) broached the theoretical possibility that tax- and bond-finance are equivalent -- "The Ricardian Equivalence Theorem." Barro (1974) argued that fiscal policy is impotent, i.e., changes in the size of budget deficits do not affect economic activity because saving is increasing. (Note 7) Buiter (1983) analyzed two effects of budget deficits on the economy. One such effect is the crowding out if they have not monetized the deficit and the other is inflation if they have monetized it.

Eisner $(1984,1986)$ took a Keynesian perspective that deficits can stimulate more employment, consumption, and investment through a Keynesian expansion. Dornbusch and Frankel (1987) argued that a shortfall in national saving, even if capital is mobile, could still drive real interest rates above world levels and crowd out domestic investments. Thomas and Abderrezak (1988) found that long-term bond yields are highly sensitive to the magnitude of expected budget deficits. Bowies, Ulbrich, and Wallace (1988) briefly outlined a theory that expansionary monetary or fiscal policy can lower the interest differentials between risky and default riskless bonds, thus reducing the crowding out effects on private spending.

Gupta (1989) showed no support for the proposition that federal deficits affect interest rates (nominal or real, ex-post or ex-ante). Cebula (1989), in a brief study, demonstrated that the federal budget deficit does act to elevate interest rates. Cebula and Koch (1989) examined the impact of deficits on long-term interest rates and provided strong empirical evidence that U.S. federal budget deficits exercise a positive, significant influence over longer-term rates of interest. Bahmani-Oskooee (1989) showed empirically that the U.S. federal budget deficit has contributed to its current account deficit.

Others argue that any attempt to correct budget deficits by raising taxes will simply cause more government spending and only increase the size of the public sector in the long term. (Note 8) Gramlich (1989) mentions that the share and the level of national saving have appeared to decline markedly in response to large deficits. Barro (1989) continues to support the Ricardian assertion that budget deficits have no first-order effect on the economy and that second-order effects arise from the distorting effects of taxes, the uncertainties of individual incomes and tax obligations, the imperfections of the credit markets, and the finite and limited nature of life. He predicts that the trend toward the Ricardian approach will continue and eventually become the benchmark for assessing fiscal policy.

Bernheim (1989) argues that, for analytical purposes, deficits should be decomposed into permanent and transitory components. (Note 9) He dismisses the Ricardian paradigm on theoretical grounds and supports the view that deficits do have real effects on the economy. Eisner (1989) disagrees sharply with the majority opinion concerning deficits. Cukierman and Meltzer (1989) present an integrated economic and political theory of public debt determination based on redistributional considerations across and within generations in the presence of ability and wealth differences. An implication of their theory is that the existence of a positive national debt is directly traceable to the existence of a sufficient number of individuals who desire to leave negative bequests but are prohibited from doing so. By voting for deficits, they increase their consumption, thus crowding out capital but reducing the severity of their bequest constraint.

Altig and Davis (1989) extend Barro's overlapping generations production economy to consider three-period lived individuals and, hence, a potentially active consumption-loans market. Their results suggest that, in both Ricardian and non-Ricardian environments, the extent of altruistic transfer motives is a key determinant of both long-run and short-run savings responses to government deficits. Abell (1990) seeks to empirically verify the set of macro linkages connecting domestic budget deficits with merchandise trade deficits. He shows that these "twin deficits" are connected through the transmission mechanisms of interest and exchange rates. Finally, Miller and Roberts (1992) mention that deficit policies may matter but existing studies do not tell us much about their effects because of an identification problem with these results. 
In this paper, a neoclassical open economy general equilibrium model is used to determine the effects of the budget deficit and national debt on interest rates, prices, exchange rates, capital accumulation, and other economic and financial variables. The scenario is as follows: an increase in the budget deficit and national debt increase the real rate of interest, and investments then decline. This increase in the real interest rate causes a capital inflow to the U.S. and the dollar appreciates. This stronger dollar increases imports and negatively affects exports, so our current account deteriorates and the capital account increases (foreign debt is accumulated). Interest payments on debt increase and taxes must eventually go up such that savings will decline, investments will fall, consumption and income will be reduced, and social welfare will deteriorate. The model is constructed and then an estimation of the model takes place. After, the empirical results of the model and its policy implications are discussed and the conclusion is given.

\section{The Structural Model}

The variables of the structural model are in natural logarithms and the model describes the determination of an open economy's rate of output and the uses to which it is put. The economy produces the needed goods and services according to the following production function:

$$
y_{t}=\alpha_{0}+\alpha_{1} k_{t-1}+\alpha_{2} n_{t}+\epsilon_{1 t}
$$

where $y$ is the aggregate real output per unit of time,

$\mathrm{k}$ is the stock of capital employed by the economy, and

$\mathrm{n}$ is the total employment used in domestic production.

We are assuming that positive, though diminishing, marginal products of capital and labor as well as direct, mutual dependencies between the marginal product of capital and employment characterize this production function. Also, we assume that the productivity of these inputs $(\mathrm{k}, \mathrm{n})$ is subject to random shocks, which we represent with the $\alpha_{0}$ here. (Note 10)

The output is divided among consumption (c), investment (I), government purchases (g), and exports minus imports represented by the current account (ca) or the balance on capital and official settlement accounts (ka).

$$
y_{t}=c_{t}+I_{t}+g_{t}-k a_{t}
$$

Equation (2) is the national income identity linking aggregate production, its components, and the foreign sector.

The economy is organized into four sectors. (1) Firms employ capital and labor to produce output. (2) The government collects taxes, purchases goods, and issues bonds to finance its expenditures, in case these costs exceed revenues. (Note 11) (3) Households own the money, the government's bonds, and equities (Note 12) of the firms. They make both a saving decision and a decision to allocate their portfolios of financial assets among bonds, equities, and money. (4) The foreign sector absorbs an amount of domestic production and partially finances domestic firms and the government.

The behavior of the firm with respect to the accumulation of capital over time is given by the function:

$$
\begin{gathered}
\frac{d k}{d t}=I_{t}=\beta_{0}+\beta_{1} r_{t}+\beta_{2}\left(g_{t}-t\right)+\beta_{3} s_{t}+\beta_{4} q_{t}+\epsilon_{3 t} \\
\beta_{1}<0, \beta_{2}<0, \beta_{3}>0, \beta_{4}>0
\end{gathered}
$$

$\underline{d k}$

Where $d t$ is the right-hand side derivative, $\mathrm{r}$ is the real cost of capital-nominal (i) minus the expected inflation ( $\pi^{e}$ ), (g-t) is the budget deficit, $\mathrm{s}$ is the saving, and $\mathrm{q}$ is the terms of trade (defined below). (Note 13) According to equation (3), the higher the supply of saving and the terms of trade, the higher the investments of the firms; but the lower that the real interest rate and the budget deficit are, the higher the investments will be as well.

The relationship between nominal and real interest rates is given by the Fisher equation.

$$
i_{t}=r_{t}+\pi_{t}^{e}=r_{t}+E\left(p_{t+1}-p_{t}\right)
$$

We assume that there is a perfect market in existing capital, in which firms, individuals, government, and foreigners can purchase or sell all the capital they want at a point in time at the going interest rate. (Note 14) Between domestic 
and foreign interest rates, an interest rate parity holds. We assume here that the forward exchange rate is an unbiased predictor of the future spot rate. (Note 15)

The terms of trade (TOT) (Note 16) or real exchange rate $(q)$ is defined as:

$$
q_{t}=p_{m}-p_{x}=e_{t}+p_{t-}^{*} p_{t}
$$

where $p_{m}$ is the price of imports, $p_{x}$ is the price of exports, $e_{t}$ is the current spot rate, $p_{t}$ is the domestic price index, and $p_{t}^{*}$ is the foreign price index.

An increase in e (currency depreciation) implies that domestic goods have become relatively cheaper and, if the Marshall-Lerner condition holds, exports are increasing and imports are falling. We refer to a rise in $\mathrm{q}$ as a terms of trade deterioration. (Note 17)

The purchasing power parity (PPP) doctrine (in its absolute version) states that the equilibrium exchange rate is equal to the difference between the domestic minus the foreign prices.

$$
e_{t}=p_{t}-p_{t}^{*}
$$

We have depicted saving (s) as a direct function of disposable income (y-t) and the real rate of interest (r), and as an indirect function of the budget deficit $(\mathrm{g}-\mathrm{t})$.

$$
\begin{gathered}
s_{t}=\gamma_{0}+\gamma_{1}\left(y_{t}-t_{t}\right)+\gamma_{2} r_{t}+\gamma_{3}\left(g_{t}-t_{t}\right)+\varepsilon_{7 t} \\
\gamma_{1>0}, \gamma_{2>0}, \gamma_{3<0}
\end{gathered}
$$

Households divide their disposable income $(y-t)$ between consumption and saving. Their demand for consumption is summarized by a consumption function that relates consumption directly to their perceived disposable income and wealth (Note 18) and the real rate of interest. (Note 19)

$$
\begin{gathered}
c_{t}=\delta_{0}+\delta_{1}\left(y_{t}-t\right)+\delta_{2} r_{t}+\delta_{3}\left(g_{t}-t_{t}\right)+\epsilon_{8 t} \\
\delta_{1}>0, \delta_{2}>0, \delta_{3}>0
\end{gathered}
$$

The foreign sector affects the domestic economy through the balance on capital and official reserve accounts. The current account (ca) plus the capital and official reserve accounts (ka) are equal to zero: $\mathrm{ca}+\mathrm{ka}=0$. The movement of goods and flows of capital among countries depend directly on the terms of trade (q) and foreign income ( $\mathrm{y}^{*}$ ) and indirectly on interest differentials $\left(\mathrm{i}-\mathrm{i}^{*}\right)$, domestic income $(\mathrm{y})$, the budget deficit $(\mathrm{g}-\mathrm{t})$, and national debt (nd).

$$
\begin{gathered}
c a_{t=}-k a_{t}=\zeta_{0}+\zeta_{1}\left(i_{t}-i_{t}^{*}\right)+\zeta_{2} q_{t}+\zeta_{3} y_{t}+\zeta_{4} y_{t}^{*}+\zeta_{5}\left(g_{t}-t_{t}\right)+\zeta_{6}\left(n d_{t}\right)+\varepsilon_{9 t} \\
\zeta_{1}<0, \zeta_{2}>0, \zeta_{3}<0, \zeta_{4}>0, \zeta_{5}<0, \zeta_{6}<0
\end{gathered}
$$

An increase in interest differentials increases the capital inflow and then the current account deteriorates because of the loss in competitiveness due to domestic currency appreciation. An increase in the terms of trade makes domestic products more competitive, so the trade account is improved. The increase in income affects positively the demand for imports while deteriorating the current account. An increase in foreign income increases demand for domestic exports, and the current account would then be improved. Finally, an increase in the budget deficit and the national debt increases the capital inflow to the U.S., thereby raising the capital account, so the current account would then decline. We choose to characterize portfolio equilibrium as equality between the supply and demand for real cash balances.

$$
\begin{gathered}
m_{t}^{s}-p_{t}=m_{t}^{d}-p_{t}=\theta_{0}+\theta_{1} y_{t}+\theta_{2} i_{t}+\theta_{3} e_{t}+\epsilon_{10 t} \\
\theta_{1}>0, \theta_{2}<0, \theta_{3}>0
\end{gathered}
$$

where $m^{s}$ is the money supply, (Note 20) $m^{d}$ is the demand for money, and $\mathrm{p}$ is a price level. The higher the real income (output as a proxy), then the higher the demand for real cash will be. The higher the interest rate, the higher the opportunity cost for holding real money balances and then the lower their demand. An increase in exchange rate (currency depreciation) increases the demand for money.

The money supply is determined by the Central Bank (the Fed), which keeps the economy at the optimal level (steady 
growth, low prices, and unemployment at the natural level) through its open market operations. In case of foreign assets flow, the Central Bank neutralizes this effect through a sterilization policy. (Note 21)

We assume that firms issue only equities (Note 22) in order to finance investment (capital budgeting). We assume also that households regard equities and bonds as perfect substitutes. This implies that their expected real yield will be equal $\left(r_{B}=r_{E}\right)$, an equality enforced by investors refusing to hold a lower yielding asset. We assume that the national debt (accumulated budget deficits) measures provide a picture of government dissaving and over-consumption. The resources of the economy are also fully employed. Tax cuts are likely to lead to higher current consumption, lower saving, and crowding out investment and net exports. (Note 23)

The last assumption is that social welfare depends on consumption, investments, and government (public) goods. Our social welfare function is an ethical one and includes not only some independent variables that satisfy our own needs (the current generation's wants) but the welfare of future generations as well. We must be altruists and try to balance our welfare with the cost of acquiring the goods and services we want to consume today.

\section{The Solution of the Model}

The Model can be summarized as consisting of ten equations, numbered (1) through (10), potentially able to determine ten variables at any moment. The endogenous variables are: Y, i, C, I, r, P, KA, S, q, and E. All of these variables are allowed to jump discontinuously as functions of time in order to satisfy the ten equations at each moment. The parameters of the model consist of the exogenous variables $\mathrm{M}, \mathrm{T}, \mathrm{G}, \mathrm{ND}, \pi, \mathrm{N}, \mathrm{K}, i^{*}, P^{*}$, and $Y^{*}$.

Equations (1), (3), (7), (8), (9), and (10) are the behavioral equations of the systems. Equation (2) is a definition of equilibrium (the National Income Identity) and equations (4), (5), and (6) are simple definitional ones. In order to solve the system, we can use a substitutional method of collapsing equations (1) through (10) into one equation where the left-hand side would have the endogenous variable(s) and the right-hand side the exogenous variables.

First, we can reduce the system of ten equations into three equations: an IS curve, an LM curve, and a CK curve. (Note 24) Taking into consideration equations (1), (2), (3), (4), (5), (6), (7), and (8), we receive the IS equation (goods market equilibrium):

$$
\begin{aligned}
& i_{r}=\frac{\alpha_{0}-\delta_{0}-\beta_{0}-\beta_{3} \gamma_{0}}{\delta_{0}+\beta+\beta_{3} \gamma_{2}}-\frac{\delta_{1}+\beta_{3} \gamma_{1}}{\delta_{0}+\beta+\beta_{3} \gamma_{2}} y_{t}+\frac{\alpha_{1}}{\delta_{0}+\beta+\beta_{3} \gamma_{2}} k_{t-1} \\
& +\frac{\alpha_{2} n_{1}+\beta_{3} \gamma_{1}}{\delta_{0}+\beta_{1}+\beta_{3} \gamma_{2}}+\frac{\delta_{3}+\beta_{2}+\beta_{3} \gamma_{3}}{o_{0}+\beta_{1}+\beta_{3} \gamma_{2}}+\pi_{t}^{e}-\frac{\delta_{0}+\beta_{1}+\beta_{3} \gamma_{2}}{\left.g_{t}-t_{t}\right)} \\
& -\frac{1}{\boldsymbol{\delta}_{\mathbf{0}}+\beta_{1}+\beta_{3} \gamma_{2}} g_{t}+\frac{1}{\delta_{0}+\beta_{1}+\beta_{3} \gamma_{2}} k a_{t}+\boldsymbol{\epsilon}_{I S}
\end{aligned}
$$

The LM Curve (money market equilibrium) is derived through equations (10) and (6) and is the following:

$$
i_{t}=-\frac{\theta_{0}}{\theta_{2}}-\frac{\theta_{1}}{\theta_{2}} y_{t}+\frac{1}{\theta_{2}} m_{t}-\frac{1+\theta_{3}}{\theta_{2}} e_{t}-\frac{1}{\theta_{2}} p_{t}^{*}+\varepsilon_{L M}
$$

The CK Curve (Note 25) is calculated by substituting equations (5) and (6) into (9).

$$
i_{t}=-\frac{\zeta_{0}}{\zeta}-\frac{\zeta_{3}}{\zeta_{1}} y_{t}+i_{t}^{*}-\frac{\zeta_{4}}{\zeta_{1}} y_{t}^{*} \cdot \frac{\zeta_{5}}{\zeta_{1}}\left(g_{t}-t_{t}\right)-\frac{\zeta_{6}}{\zeta} n d_{t}-\frac{1}{\zeta_{1}} k a_{t}+\varepsilon_{C K}
$$

The system of equations (I), (II), and (III) can be presented at the following IS-LM-CK diagram, as Figure 1 shows. This basic macroeconomic model of flexible exchange rates has been developed under conditions of perfect capital mobility. The model is a direct extension of the IS-LM model. The openness of the economy is introduced through two channels. The relative price of domestic goods in terms of importables is a determinant of the composition of spending, and net exports $(\mathrm{CA}=-\mathrm{KA})$ are a component of the demand for domestic output. The other channel is the linkage of interest rates in an integrated world capital market. 


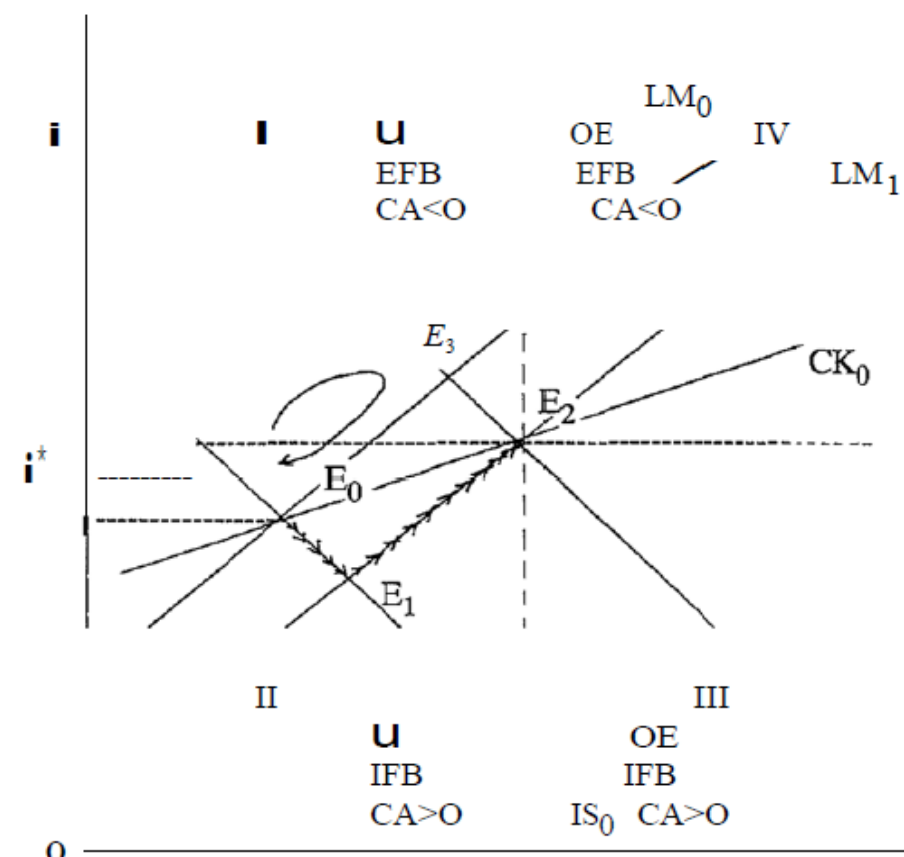

0

\section{y}

Figure 1. The IS-LM-CK three market diagram ( $\left.\mathrm{S}=\mathrm{I}, M^{d}=M^{S} \mathrm{GA}=-\mathrm{KA}\right)$

$\mathrm{U}=$ unemployment, $\mathrm{OE}=$ overemployment, $\mathrm{EFB}=$ excessive net foreign borrowing, $\mathrm{IFB}=$ insufficient net foreign borrowing, and $\mathrm{CA}=$ current account

In Figure 1, we show the model in an initial full equilibrium at point E0. The LM schedule shows monetary equilibrium according to equation (II), the schedule being drawn for given money stock, exchange rate, and foreign prices. The IS schedule is drawn for given capital stock, labor force, taxes, expected inflation, budget deficit, government spen- ding, and capital account, according to equation (I). The CK schedule denotes satisfac- tion of equation (III)'s current account (capital account) target (Note 26) and is drawn for given foreign interest rate, foreign real income, budget deficit, national debt, and capital account.

In a case of monetary expansion, nominal balances increase and, because prices are sluggish in their adjustment, we have a rise in real money. The ensuing monetary disequilibrium leads to a fall in interest rates and an expansion in real income as the LM schedule shifts to the right (LM1). The economy moves from point E0 to point $E_{1}$ where goods and money markets clear and the current account is improved. Point E1 is not an equilibrium because the interest rate has fallen and there is a tendency for capital outflows, creating our capital account deficit and thus leading to our currency depreciation.

The depreciation lowers the relative price of domestic goods (Note 27), raises the demand for domestic output, and thus shifts the IS curve up and to the right (IS1). Depreciation, induced by incipient capital outflows, leads to a rise in income. The depreciation continues until income has expanded sufficiently to restore monetary equilibrium at point $E_{2}$

The income expansion induced by an increase in nominal money is due entirely to currency depreciation and the current account improvement associated with a fall in the relative price of our goods. Monetary expansion raises output and employment through an improvement in the current account.

Consider next a fiscal expansion or a rise in the budget deficit. At the initial level of interest rates, exchange rates, and income, there is an excess demand for goods and accordingly the IS curve shifts outward to IS1, raising income and the rate of interest (point E3). Incipient capital inflows now lead to exchange appreciation and thus to a loss in competitiveness. Demand shifts away from domestic goods, leading the IS curve to shift back toward its initial position.

The process of exchange (\$) appreciation will continue as long as the interest rate exceeds the world level. Given the 
money stock, currency appreciation will continue as long as output is above its initial level. It follows then that currency appreciation will proceed until the initial equilibrium is reestablished (back to point E0). The exchange appreciation leads to a current account deterioration that fully offsets the initial demand expansion. With full crowding out, demand expansion leaves output unaffected as long as there is no corresponding increase in real balances.

The system of equations (I), (II), and (III) can be solved simultaneously to determine the output or real income ( $\left.Y_{t}\right)$ of the economy as a function of the exogenous variables and the spot exchange rate $\left(e_{t}\right)$, and for all the other endogenous variables as dependent variables and all the exogenous variables as independent ones.

$$
\begin{aligned}
& {\left[-\frac{\theta_{1}}{\theta_{2}}\left(\delta_{2}+\beta_{1}+\beta_{3} \gamma_{2}+\zeta_{1}\right)+\delta_{1}+\beta_{3} \gamma_{1}+\zeta_{3}\right] y_{t}=} \\
& +\frac{\theta_{0}}{\theta_{2}}\left(\delta_{2}+\beta_{1}+\beta_{3} \gamma_{2}+\zeta_{1}\right)+\alpha_{0}-\delta_{0}-\beta_{0}-\beta_{3} \gamma_{0}-\zeta_{0} \\
& -\frac{1}{\theta_{2}}\left(\delta_{2}+\beta_{1}+\beta_{3} \gamma_{2}+\zeta_{1}\right) m_{t} \\
& +\frac{1+\theta_{3}}{\theta_{2}}\left(\delta_{2}+\beta_{1}+\beta_{3} \gamma_{2}+\zeta_{1}\right) e_{x} \\
& +\left(\delta_{2}+\beta_{1}+\beta_{3} \gamma_{2}\right) \pi_{t}^{e} \\
& \frac{1}{\theta_{2}}\left(\delta_{2}+\beta_{1}+\beta_{3} \gamma_{2}+\zeta_{1}\right) p_{t}^{*} \\
& \begin{array}{l}
+\alpha_{1} k_{t-1} \\
+\quad \alpha_{2} n_{t}
\end{array} \\
& +\left(\delta_{1}+\beta_{3} \gamma_{1}\right) t_{t} \\
& -\left(\delta_{3}+\beta_{2}+\beta_{3} \gamma_{3}-\zeta_{5}\right)\left(g_{t}-t_{t}\right) \\
& +\zeta_{1} i_{t}^{*} \\
& -\zeta_{4} y_{t}^{*} \\
& -\zeta_{\sigma^{n}} \varepsilon_{t} d_{t}
\end{aligned}
$$

From the above equation, we can see the effect of budget deficit $\mathrm{d}(\mathrm{gt}-\mathrm{tt})$ on real income dyt:

$$
\begin{array}{cc}
d y_{t} & -\left(\delta_{3}+\beta_{2}+\beta_{3} \gamma_{3}-\zeta_{5}\right) \\
\hdashline\left(g_{t}-t_{t}\right) & -\theta_{1} / \theta_{2}\left(\delta_{2}+\beta_{1}+\beta_{3} \gamma_{2}+\zeta_{1}\right)+\delta_{1}+\beta_{3} \gamma_{1}+\zeta_{3}
\end{array}
$$

By looking at the above multiplier, we can see the effect of the budget deficit on real income and we can also find the effect of the budget deficit $\left(g_{t}-t_{t}\right)$ on the other endogenous variables (i, C, I, r, P, KA, S, q, and E) if we follow the same method.

We have to estimate ten reduced forms of equations that have as a dependent variable one of our ten endogenous variables and also have as independent ones the exogenous variables of the system plus the spot exchange rate. First, we have to estimate the endogenous variable $e_{t}$ by using instrumental variables (IV) -- proxies for endogenous variables created as linear combinations of the exogenous variables or lagged endogenous ones.

$$
e_{t}=f\left(m_{t-1}-m_{t-1}^{*}, y_{t-1}-y_{t-1}^{*}, i_{t-1}-i_{t-1}^{*}, C A_{t-1}-C A_{t-1}^{*}, B D_{t-1}-B D_{t-1}^{*}, N D_{t-1}-N D_{t-1}^{*}\right)
$$


Then, the ten reduced form equations are:

$$
\begin{gathered}
y_{t}=f\left(m_{t}, e_{t}, \pi_{t}, p_{t}^{*}, k_{t-1}, n_{t}, t_{t}, g_{t}, g_{t}-t_{t}, i_{t}^{*}, y_{t}^{*}, n d_{t}\right) \\
i_{t}=f\left(m_{t}, e_{t}, \pi_{t}, p_{t}^{*}, k_{t-1}, n_{t}, t_{t}, g_{t}, g_{t}-t_{t}, i_{t}^{*}, y_{t}^{*}, n d_{t}\right) \\
c_{t}=f\left(m_{t}, e_{t}, \pi_{t}, p_{t}^{*}, k_{t-1}, n_{t}, t_{t}, g_{t}, g_{t}-t_{t}, i_{t}^{*}, y_{t}^{*}, n d_{t}\right) \\
I_{t}=f\left(m_{t}, e_{t}, \pi_{t}, p_{t}^{*}, k_{t-1}, n_{t} t_{t}, g_{t}, g_{t}-t_{t}, i_{t}^{*}, y_{t}^{*}, n d_{t}\right) \\
r_{t}=f\left(m_{t}, e_{t}, \pi_{t}, p_{t}^{*}, k_{t-1}, n_{t} t_{t}, g_{t}, g_{t}-t_{t}, i_{t}^{*}, y_{t}^{*}, n d_{t}\right) \\
p_{t}=f\left(m_{t}, e_{t}, \pi_{t}, p_{t}^{*}, k_{t-1}, n_{t}, t_{t}, g_{t}, g_{t}-t_{t}, i_{t}^{*}, y_{t}^{*}, n d_{t}\right) \\
k a_{t}=f\left(m_{t}, e_{t}, \pi_{t}, p_{t}^{*}, k_{t-1}, n_{t}, t_{t}, g_{t}, g_{t}-t_{t}, i_{t}^{*}, y_{t}^{*}, n d_{t}\right) \\
s_{t}=f\left(m_{t}, e_{t}, \pi_{t}, p_{t}^{*}, k_{t-1}, n_{t}, t_{t}, g_{t}, g_{t}-t_{t}, i_{t}^{*}, y_{t}^{*}, n d_{t}\right) \\
q_{t}=f\left(m_{t}, e_{t}, \pi_{t}, p_{t}^{*}, k_{t-1}, n_{t}, t_{t}, g_{t}, g_{t}-t_{t}, i_{t}^{*}, y_{t}^{*}, n d_{t}\right) \\
e_{t}=f\left(m_{t}, e_{t}, \pi_{t}, p_{t}^{*}, k_{t-1}, n_{t}, t_{t}, g_{t}, g_{t}-t_{t}, i_{t}^{*}, y_{t}^{*}, n d_{t}\right)
\end{gathered}
$$

The ten equations above (13) can be solved using a Two-Stage Least Squares (2SLS) method. Solve for each of the equations in (13) with equation (12) and we will have the effects of the independent variables on our endogenous dependent variables.

\section{Empirical Results}

The data come from three major sources: Survey of Current Business, U.S. Department of Commerce, Main Economic Indicators, OECD, and International Financial Statistics, IMF. All of the data are reported on a quarterly basis. The foreign variables are weighted average values of the twelve major countries with which the United States has the higher volume of trade $(\mathrm{T}=\mathrm{X}+\mathrm{M})$. (Note 28) The trade data are coming from the Direction of Trade Statistics Yearbook, IMF; the weights are constructed as $W_{j}=T j$.

$$
\sum_{j=1}^{12} T_{j}
$$

The trade data are from 1981 to 1987 . (Note 29) The lower case variables represent natural logarithms of their upper case counterparts.

First, we estimate equation (12), where $e_{t}$ is an endogenous variable, and these estimates are used for the two-stage least squares (2SLS) estimation of the ten equations in (13). The results are as follows:

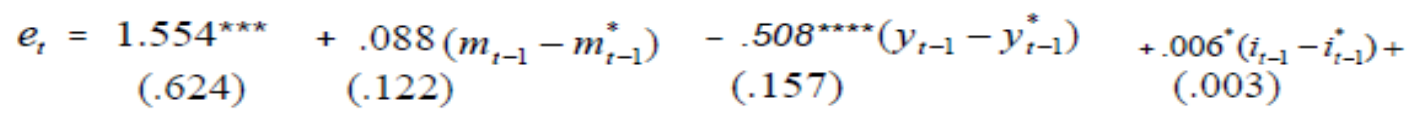

$$
\begin{array}{ccc}
1.3 E-11\left(C A_{t-1}-C A_{t-1}^{*}\right)+ & 3.5 E-6\left(B D_{t-1}-B D_{t-1}^{*}\right)-9.3 E-6\left(N D_{t-1}-N D_{t-1}^{*}\right)+.970^{* * * *} e_{t-1} \\
(2.5 E-10) & (2.1 E-6) & (1.8 E-5)
\end{array}
$$

$\mathrm{R} 2=.958, \mathrm{P}-\mathrm{W}=1.787, \mathrm{~F} 7,42=136.982, \mathrm{df}=42$

The results of the reduced-form equations in (13) appear in Table 1 below where an Ordinary Least Squares (OLS) method and either an Instrumental Variables (IV) or a2SLS method have been used. 
Table 1. Estimation results of equations (13)

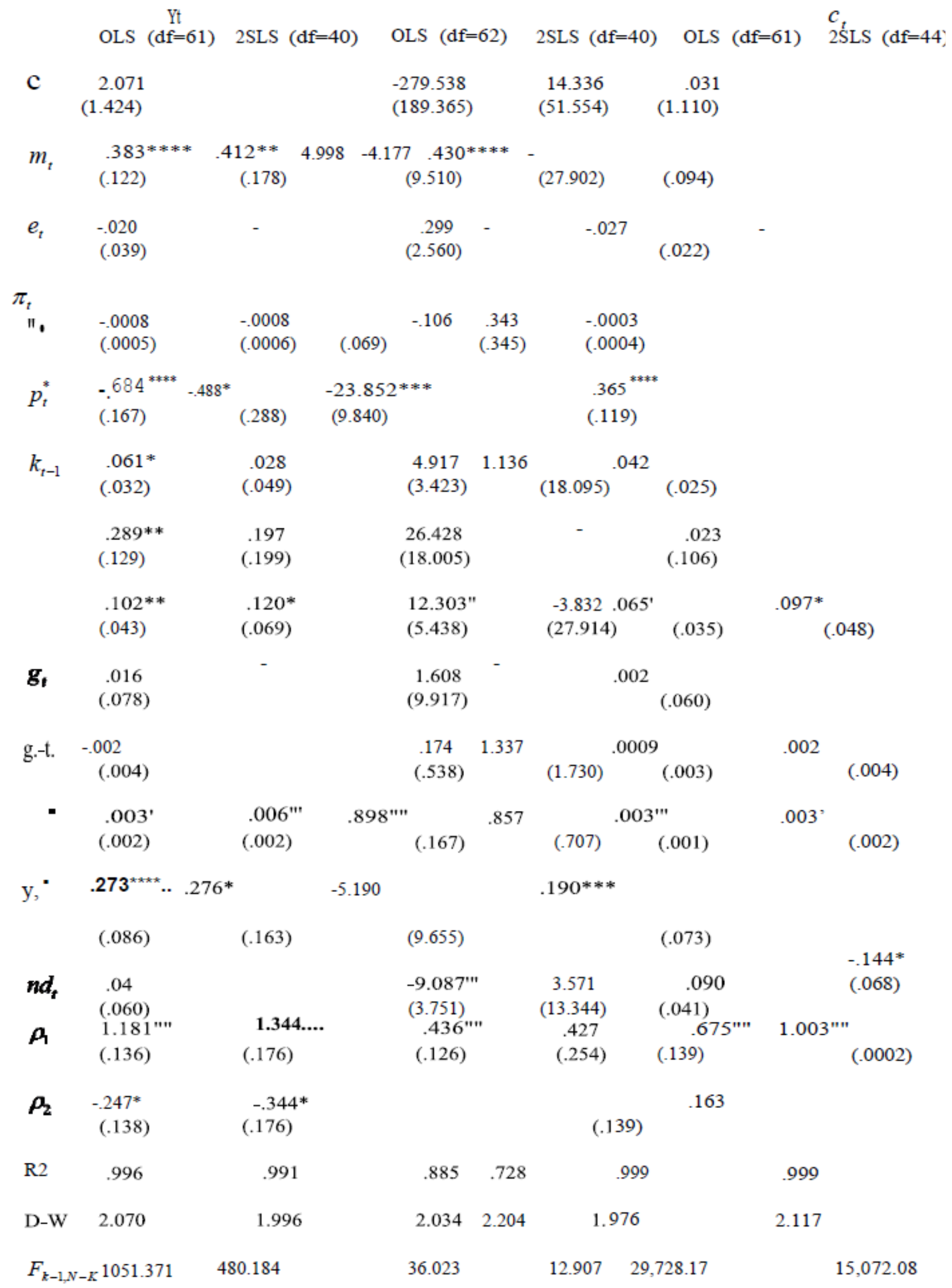




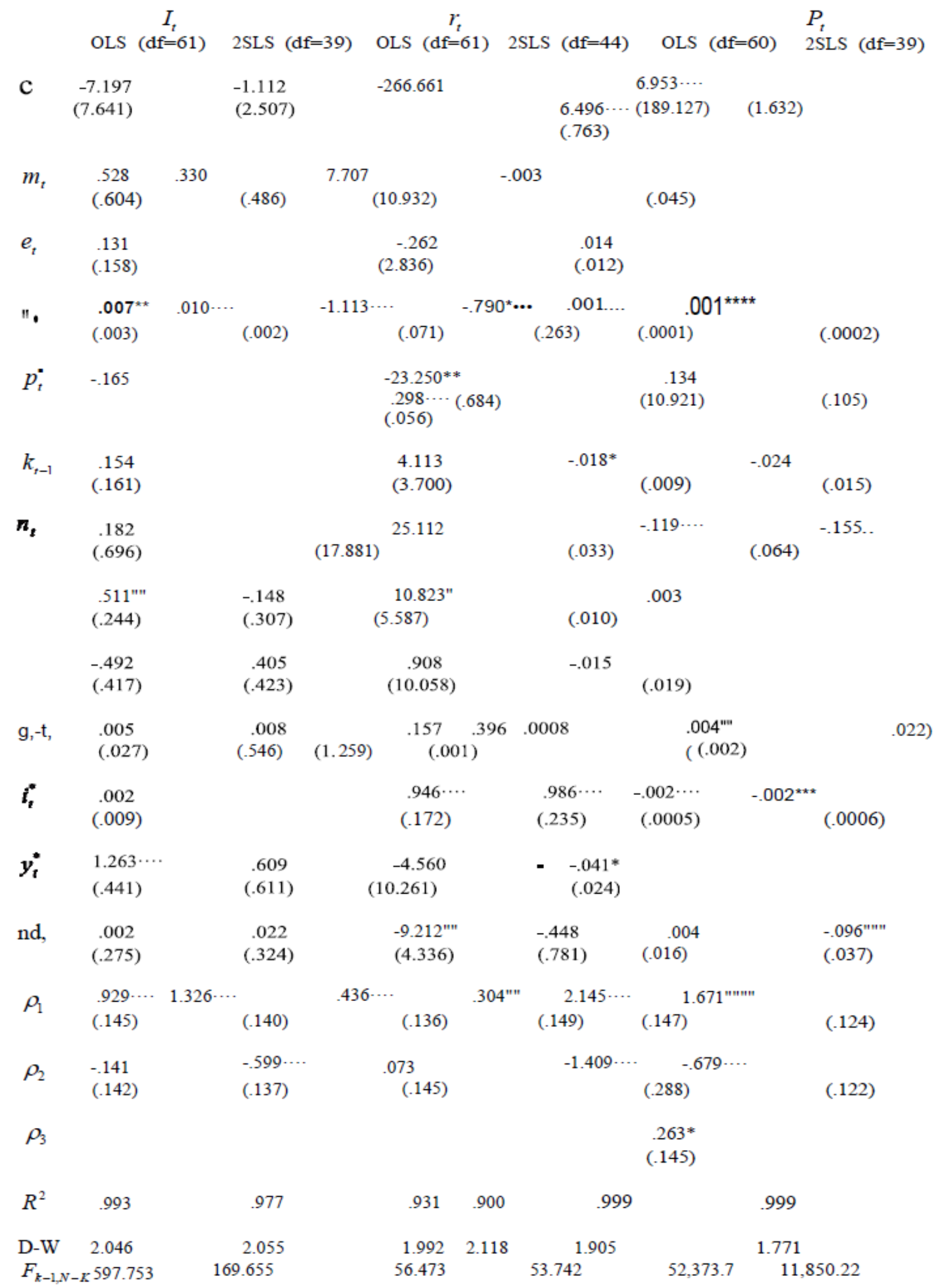




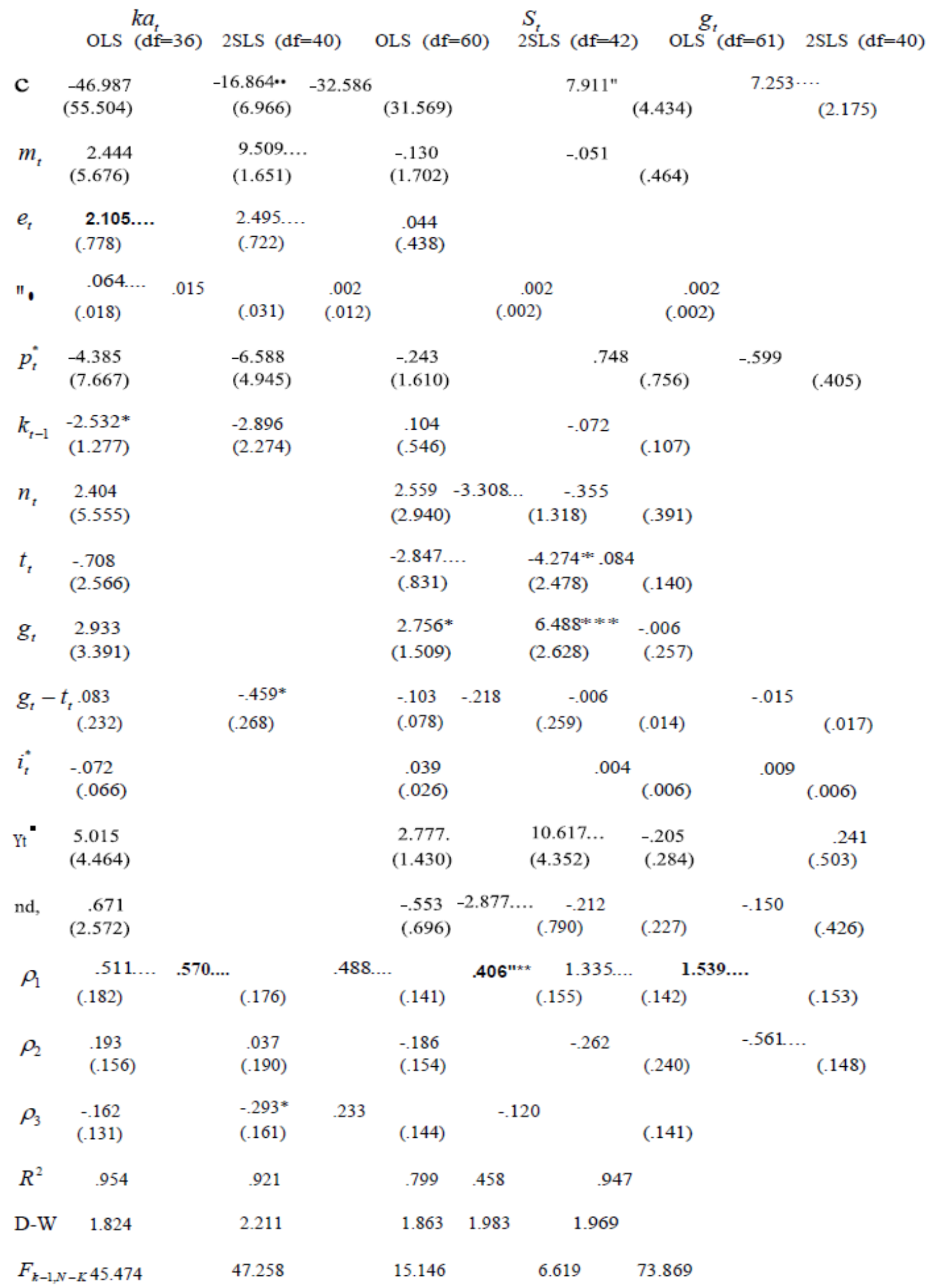


Notes: Standard errors are in parentheses below the parameter estimates. The estimations are corrected for serially correlated errors. The Durbin-Watson statistic is reported for the corrected estimations. Estimation methods: OLS=Ordinary Least Squares; 2SLS=Two- Stage Least Squares by using equation (12) as instrumental variables.

*** statistically significant at the 1 percent level

*** statistically significant at the 2 percent level

** statistically significant at the 5 percent level, and

* statistically significant at the 10 percent level.

The majority of the coefficients carry their expected signs. The OLS estimates are reported by treating the effective exchange rate $\left(e_{t}\right)$ as exogenous, which is not true, but the 2SLS estimates are unbiased because the effective exchange rate is treated as endogenous.

We see that the budget deficit has a significant effect on prices and the current account deficit. The national debt also has a significant effect on consumption and saving.

Other significant effects that we can see from Table 1 are the following: the money supply significantly affects real income, consumption and the current account; the effective exchange rate affects the current account; the inflation rate affects investments, the real rate of interest, the price level, and the current account; the foreign price level affects real income, the interest rate, consumption, the real interest rate, and the price level in the U.S.; the capital accumulation of the economy affects real income, the price level, and the current account; the labor force affects real income, prices, and saving; taxes affect real income, the interest rate, consumption, investment, the real rate of interest, and saving; government expenditures affect saving; the foreign interest rate affects real income, the domestic interest rate, consumption, the real rate of interest, and the price level; finally, foreign real income affects domestic real income, consumption, investment, prices, and saving.

\section{Policy Implications}

There are different scenarios by which crowding outs can occur. One is when a switch from tax to deficit finance raises both real and nominal interest rates and crowds out investment. Another mechanism, with internationally mobile capital, will crowd out net exports rather than domestic investment. Budget deficits place an upward pressure on interest rates and cause an inflow of foreign funds to the U.S. With flexible exchange rates, this influx of capital causes the country's currency to appreciate, which diminishes its competitiveness in world markets and deteriorates its current account.

The implications on future living standards are as follows. High deficits retard domestic capital formation and shift the economy onto a growth path of lower per capita output and lower capital per worker and therefore cause a reduction of the marginal product of labor. Current account and budget deficits induce growing foreign indebtedness and result in a burden of future interest payments that will lower the disposable income of domestic residents.

Government deficits place pressures on the balance of payments and on the credit markets only if they are not offset by saving elsewhere in the economy. If the pool of private saving is small, the federal deficit (government expenditures) and private investment will be in a severe competition for funds. This situation will affect the interest rate (the cost of capital) and private investment and the current account will lose (the "crowding out effect").

Budget deficits and national debts have been quite common among the industrialized countries of the world since the 1980 s, but private saving rates in some of these countries have exceeded their deficits by very satisfactory margins (e.g., Japan). In the U.S., private saving (Note 30) since the 1980s has been absorbed by the combined deficits of federal, state, and local governments. Private activities have declined due to the high real and nominal rates of interest as well as the credit crunch in the economy. The demand for durables has declined (especially for automobiles, a major industry in the United States). The demand for mortgages (real estate) has fallen dramatically because of high mortgage rates, the credit crunch, and the recession that started in the third quarter of 1990 and continued until the first quarter of 1991. Inventory demand has been reduced because of the high cost of capital and has affected the expansion and modernization of firms.

As Greenspan (1989) mentions, net investment in the U.S. has fallen to 4.7 percent of GNP in the 1980s from an average level of 6.7 percent in the 1970s, and even higher in the 1960s. This rate is low, not only by U.S. historical standards, but by international standards as well. These are some indications that capital accumulation in the country has declined drastically. The results might have been worse had we not had the net inflows of foreign saving, as we can see from our capital account, which is an important addition to domestic saving. Of course, this foreign saving may not 
be a reliable substitute for domestic saving on a long term basis because many other countries around the world are competing for the same funds. Domestic saving is the only source of funds that can support domestic investment in the long run. We must find ways to gradually reduce this current trend but at the same time we must avoid a significant reduction in our standard of living. Moderation in all things is very important.

Others believe that public debt in the Western world is proof of overconsumption and bad management of the current generation. The government might have to increase taxes in the future (as this administration is planning to do) to finance these huge deficits and such a planned increase will reduce the net disposable income and consumption of individuals who are not yet born. In other words, this generation is using resources that belong to the next generation without asking permission to use them. Since Barra's altruistic transfers and intergenerational linkage are not obvious today, his conclusion concerning the irrelevance of government finance is far from reality. The human ego (absolute self-interest) does not allow us to become altruists and care for the social needs or interests of future generations even though they are our immediate descendants (our children).

Public sector deficits are frowned on, condemned by, and battled against by financial managers, central bankers, international financial institutions, and many economists. Even if capital mobility enforces parity among interest rates, when expressed in terms of a common currency, a country that suffers a shortfall in national saving can still drive its real interest rate above world levels and thus crowd out domestic investment. (Note 31) The government budget deficit will affect real growth, consumption, saving, inflation, public sector capital formation, and cyclical derivations of actual trend output, and it will make fiscal policy ineffective (as happened during the 1990-91 recession). (Note 32)

\section{Conclusion}

The theoretical model shows that deficits do matter but the empirical results cannot exactly support this theory. The methods (OLS and 2SLS) are not so efficient and there are many problems with the data at the same time. (Note 33) From Table 1, we see that budget deficit

and national debt affect all the variables in question and there are significant effects on prices, the current account, consumption, and saving. We can also see the interdependence and repercussion effects among the U.S. economy and the rest of the world by looking at the significant effects of world interest rates and foreign real income on the U.S. variables.

Over the long term, these deficits might have a negative effect on the economy. We experienced a rather large degree of slack in the economy in the early years of the 1980s expansion. This slack meant that the economy could not accommodate growing demands from both the private and public sectors. The problem there was that these demands could not be accommodated from domestic resources, so we went abroad and imported them; the results appeared in our large current account deficit. This reliance on foreign sources of funds cannot continue forever.

Deficits must be financed by borrowing or taxing or through "high-powered" domestic credit expansion. In an open economy with a freely floating exchange rate, "high-powered" domestic credit expansion equals the rate of change of the monetary base. If deficits are financed through the federal government's printing of money, then this will fuel inflation. Financing the deficits by increasing taxes will negatively affect production, consumption, saving, and income. Lastly, if they are financed by borrowing, then this will put upward pressure on interest rates, leading to the "crowding out" of interest-sensitive spending (private investment) and the current account. Even at given interest rates, "crowding out" could occur, with government bonds displacing claims to private capital in private portfolios (because investors are risk averse).

These large and persistent deficits are slowly but implacably damaging the economy. The damage occurs because the public sector tends to pull resources away from the private sector. This lack of resources in business firms reduces net investment and negatively affects the rate of growth of the nation's capital stock which, in turn, affects the capital-to-labor ratio in the economy, reduces labor productivity, and leads to a deterioration in the overall standard of living.

Economists and policymakers must have a longstanding and strong interest in questions about interest rates, savings, investments, capital accumulation, and the welfare effects of government debt policies and fiscal policies that redistribute resources between living generations. Budget deficits raise total lifetime consumption by shifting taxes to subsequent generations. (Note 34) Much of the existing macroeconomic evidence supports the neoclassical view that deficits have real effects on the economy. Therefore, the neoclassical paradigm must offer the most relevant insights for public fiscal policy and action ought to be taken for a gradual reduction of deficits through a reduction in government spending and not by a drastic increase in taxes.

In general, budget deficits raise current consumption (due to low taxes and the "wealth effect") at the expense of lower 
consumption in the future. Of course, we do not know how much time is required for a dramatic change in the saving rate to show a substantial reduction in the economy's capital accumulation. If the debt continues to increase (either because of overconsumption by the public sector or insufficient taxes), the government's borrowing will have to increase to pay even the interest on its outstanding debt. In periods of recession (as has happened recently), where the output, income, and saving are low and real interest rates are usually high, it will be very difficult for the government to increase either taxes or borrowing because doing so will more rapidly bring the economy to a crisis characterized by sharp declines in consumption, investment, and aggregate demand, and consequently in output and employment, because of the reduction in disposable income and the severe crowding out.

\section{References}

Abell, John D. (1990). Twin Deficits during the 1980s: An Empirical Investigation. Journal of Macroeconomics, 12(1), Winter, 81-96.

Altig, David, \& Steve J. Davis. (1989, July). Government Debt, Redistributive Fiscal Policies, and the Interaction between Borrowing Constraints and Intergenerational Altruism. Journal of Monetary Economics, 24(1), 3-29.

Bahmani-Oskooee, Mohsen. (1989). Effects of the U.S. Government Budget on Its Current Account: An Empirical Inquiry. Quarterly Review of Economics and Business, 29(4), Winter, 76-91.

Barro, Robert J. (1974, November/December). Are Government Bonds Net Wealth?. Journal of Political Economy, 82, 1095-1117.

(1989). The Ricardian Approach to Budget Deficits. Journal of Economic Perspective, 3, Spring, 37-54.

Bernheim, B. Douglas. (1989). A Neoclassical Perspective on Budget Deficits. Journal of Economic Perspectives, 3, Spring, 55-72.

Bowies, David, Holley Ulbrich, \& Myles Wallace. (1988, July). Default Risk and the Effects of Fiscal Policy on Interest Rates: 1929-1945. Public Finance Quarterly, 16(3), 357-373.

Buiter, Willem H. (1983). Deficits, Crowding out and Inflation: The Simple Analytics. National Bureau of Economic Research, Working Paper No. 1078, February.

Cebula, Richard. (1989). More on Budget Deficits and Interest Rates in the United States. Public Choice, 60, 93-97.

Cebula, Richard, \& James Koch. (1989). An Empirical Note on Deficits, Interest Rates and International Capital Flows. Quarterly Review of Economics and Business, 29(3), Autumn, 121-127.

Cukierman, Alex, \& Allan H. Meltzer. (1989, September). A Political Theory of Government Debt and Deficits in a Neo-Ricardian Framework. American Economic Review, 79(4), 713-732.

Dornbusch, Rudiger, \& Jeffrey Frankel. (1987). The Flexible Exchange Rate System: Experience and Alternatives. NBER Working Paper No. 2464, December, 1-78.

Eisner, Robert. (1986). How Real is the Federal Deficit?. New York: The Free Press, A Division of Macmillan. (1989). Budget Deficits: Rhetoric and Reality. Journal of Economic Perspectives, 3, Spring, 73-93.

Eisner, Robert, \& Paul J. Pieper. (1984, March). A New View of the Federal Debt and Budget Deficits. American Economic Review, 11-29.

Freeman, Scott. (1992). Money and Output: Correlation or Causality? Economic Review, Federal Reserve Bank of Dallas, Third Quarter, 1-7.

Gramlich, Edward M. (1989). Budget Deficits and National Saving: Are Politicians Exogenous?. Journal of Economic Perspectives, 3(2), Spring, 23-35.

Greenspan, Alan. (1989, January-February). Deficits Do Matter. Challenge, 51-54.

Gupta, Kanhaya. (1989). Budget Deficits and Interest Rates in the United States. Public Choice, 60, 87-92.

Kallianiotis, Ioannis N. (1988, December). A Theoretical Monetary and Real Approach to the Balance of Payments. Greek Economic Review, 10(2), 383-404.

Kallianiotis, Ioannis N. (1991). Is the U.S. Budget Harming the Financial Markets and the Overall Economy?. Research Report Series No. 9110, University of Scranton, SOM, October.

Papadogonas, T., \& Y. Stournaras. (2006). Twin Deficits and Financial Integration in EU Member States. Journal of Policy Modelling, 28, 701-712. 
Ricardo, David. (1951). Funding System. In Sraffa, Piero (Ed.), The Works and Correspondence of David Ricardo, (Vol. IV). Pamphlets and Papers, 1815-1823. Cambridge, U.K.: Cambridge University Press.

Thomas, Lloyd B., Jr., \& Ali Abderrezak. (1988, July). Long-term Interest Rates: The Role of Expected Budget Deficits. Public Finance Quarterly. 16(3), 341-356.

Trachanas E., \& C. Katrakilidis. (2013). The Dynamic Linkages of Fiscal and Current Account Deficits: New Evidence from Five Highly Indebted European CountriesAccounting for Regime Shifts and Asymmetries. Economic Modelling, 31, 502-510.

Vamvoukas, G.A. (1999). The Twin Deficits Phenomenon: Evidence from Greece. Applied Economics, 31, 1093-1000.

\section{Notes}

Note 1. See "Pay Now Or Pay Later," Washington Post National Weekly Edition, July 31 - August 6, 1989, p. 5.

Note 2. See Kallianiotis and Khinvasara (1991) and Dornbusch and Frankel (1987).

Note 3. David Ricardo (1951) believed that tax-finance and bond-finance are equivalent.

Note 4. See Bernheim (1989), Eisner (1989), and Kallianiotis (1991).

Note 5. See Buiter (1983).

Note 6. It makes no difference whether government spending was financed by borrowing or by raising taxes because in either case aggregate demand increased through saving and investment or through government spending, respectively.

Note 7. Gallaway and Frenze (1987) call this the "tax and spend" view.

Note 8 . The Neoclassical paradigm provides a good theory of the permanent components, while the Keynesian framework describes the effect of the temporary component.

Note 9. See Freeman (1992, p. 2).

Note 10. The money is issued by the Central Bank through open market operations.

Note 11. By "equities," we mean corporate stocks.

Note 12. Two other independent variables could be the marginal product of capital or the IRR and the national debt (nd).

Note 13. This interest rate is the nominal yield on government bonds and private stocks (equities).

Note 14. The exchange rate is quoted in direct terms, namely, domestic currency per unit of foreign currency (e.g., $\$ / \mathrm{DM})$.

Note 15. The exchange rate is flexible and affects macroeconomic equilibrium because, with given prices at home and abroad, changes in the exchange rate change the TOT and therefore affect the allocation of demand, output, and employment in turn.

Note 16. See Kallianiotis (1988).

Note 17. The budget deficit (g-t) has increased the holding of bonds by households. This increases their nominal wealth, which affects consumption (the "wealth effect").

Note 18. The higher the real rate of interest, the more costly it is for households to borrow money to purchase housing and other investment goods, so they increase consumption of goods and services as a result. Consumption plus saving equals disposable income $(\mathrm{c}+\mathrm{s}=\mathrm{y}-\mathrm{t})$.

Note 19. Money is measured in domestic monetary units (i.e., dollars) and can be exchanged for other currencies through an exchange rate e, measured in units of domestic currency per unit of foreign currency (direct quotation). It bears a nominal yield that is fixed to zero. Its real yield is equal to $\left(-\pi^{e}\right)$ (expected inflation rate:

$\pi^{e}=\Delta P / P=\lambda(\Delta M / M)$,

where $\lambda$ is the speed of price adjustment). There is a gradual adjustment of prices; see Kallianiotis (1988).

Note 20. By using an open market operation, a sterilization policy offsets the effect of capital flows on the domestic monetary base and, consequently, on the money supply. Here then, the public policy is pursued through the Central Bank. 
Note 21 . There are no corporate bonds or retained earnings.

Note 22. If resources are fully employed, output is fixed $\left[\bar{Y}=\mathrm{c}^{\uparrow}+I \downarrow+G+(X-M) \downarrow\right]$.

Note 23. CK is a Current Account-Capital Account equilibrium curve.

Note 24. Along CK0, we satisfy the current account target. Higher income worsens the current account, calling for a real exchange depreciation so as to restore the current account to the target level (external balance). Above the CK0 schedule, the current account is below target, and below it we have an excessive current account surplus.

Note 25. We want a proper policy mix for internal and external balance. Internal balance is defined as full employment $\left(Y_{f}\right)$ and the external balance target $(\mathrm{CK} 0)$ is defined as $\mathrm{CA}=-\mathrm{KA}=0$, which shows that the country does not wish to either borrow or lend abroad excessively.

Note 26. $q=\uparrow E P^{*} / P=\uparrow P M / P_{x} \rightarrow P_{x} \downarrow$

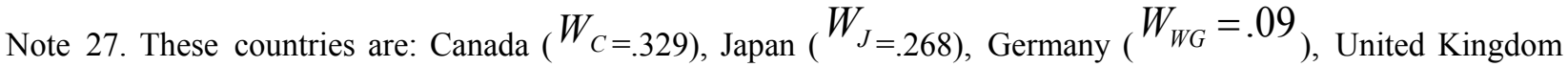

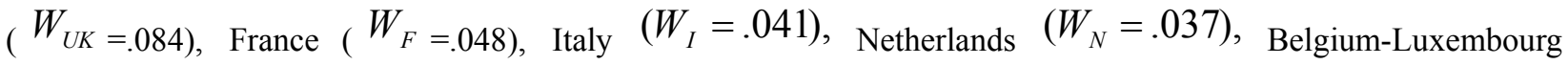
$\left(W_{B+L}=.026\right)$, Australia $\left(W_{A}=.025\right)$, Switzerland $\left(W_{S W}=.02\right)$, Spain $\left(W_{S}=.017\right)$, and Sweden $\left(W_{S D=.016)}\right.$

Note 28. Our foreign variables $i^{*}, \mathrm{P}^{*}, \mathrm{Y}^{*}, \mathrm{M} 2{ }^{*}, \mathrm{CA}^{*}, \mathrm{BD}^{*}$ and $\mathrm{ND}^{*}$ are, for example, represented by $i^{*}=\sum_{j=1}^{12} w_{j} i$. Note 29. With private saving, we mean households' saving, firms' retained earnings, and depreciation (supplier of funds). Demanders of funds, on the other hand, are investment firms and governments that need their deficits financed.

Note 30. See Dornbusch and Frankel (1987, p. 14).

Note 31 . The government was unable to either reduce taxes or increase spending to stimulate the economy because of these tremendous deficits.

Note 32. Our plans are to estimate the original model by using a Full Information Maximum Likelihood (FIML) method.

Note 33. They create many externalities but a few of them can be considered positive. 